Le Quéré, A., D. P. Wright, B. SöDerström, A. Tunlid and T. JoHANSSON (2005): Global patterns of gene regulation associated with the development of ectomycorrhiza between birch (Betula pendula Roth.) and Paxillus involutus (Batsch) Fr. Mol Plant-Microbe Interact 18: 659-673.

LI, L., S. LU and V. ChIANG (2006): A genomic and molecular view of wood formation. Crit Rev Plant Sci 25: 215-233.

Lindahl, B. O., A. F. S. TAYLOR and R. D. Finlay (2002): Defining nutritional constraints on carbon cycling in boreal forests - towards a less 'phytocentric' perspective. Plant Soil 242: 123-135.

Lloyd, G. and B. McCown (1980): Commercially-feasible micropropagation of Mountain Laurel, Kalmia latifolia, by use of shoot-tip culture. Int Plant Prop Soc Proc 30: 421-427.

MARX, D. H. (1969): The influence of ectotrophic fungi on the resistance of pine roots to pathogenic infections. I. Antagonism of mycorrhizal fungi to root pathogenic fungi and soil bacteria. Phytopathology 59: 153-163.

Morel, M., C. JACOB, A. KOHLER, T. JOHANSSON, F. Martin, M. Chalot and A. Brun (2005): Identification of genes differentially expressed in extraradical mycelium and ectomycorrhizal roots during Paxillus involutus-Betula pendula ectomycorrhizal symbiosis. Appl Environ Microbiol 71: 382-391.

Morin, C., J. SAmson and M. Dessureault (1999): Protection of black spruce seedlings against Cylindrocladium root rot with ectomycorrhizal fungi. Can $\mathrm{J}$ Bot $\mathbf{7 7}$ : 169-174.

NiemI, K. and H. HäGGMAN (2002): Pisolithus tinctorius promotes germination and forms mycorrhizal structures in Scots pine somatic embryos in vitro. Mycorrhiza 12: 263-267.

Niemi, K., H. HäGGMAN and T. SARJALA (2002): Effects of exogenous diamines on the interaction between ectomy- corrhizal fungi and adventitious root formation in Scots pine in vitro. Tree Physiol 22: 373-381.

Niemi, K., M. Salonen, A. Ernstsen, H. Heinonen-Tanski and H. HÄGGMAN (2000): Application of ectomycorrhizal fungi in rooting of Scots pine fascicular shoots. Can J For Res 30: 1221-1230.

NiEMI, K., C. SCAGEL and H. HÄGGMAN (2004): Application of ectomycorrhizal fungi in vegetative propagation of conifers. Plant Cell Tissue Organ Cult 78: 83-91.

Pilate, G., E. Guiney, K. Holt, M. Petit-Conil, C. Lapierre, J.-C. Leplé, B. Pollet, I. Mila, E. A. WebSter, H. G. Marstorp, D. W. Hopkins, L. Jouanin, W. Boeruan, W. Schuch, D. Cornu and C. Halpin (2002): Field and pulping performances of transgenic trees with altered lignification. Nat Biotechnol 20: 607-612.

Rolando, C., B. Monties and C. LAPIERRe (1992): Thioacidolysis, pp 334-349. In: Methods in lignin chemistry, edited by LIN, S. Y. and C. W. DENCE, Springer-Verlag, Berlin.

SARKANEN, K. V. and H. L. Hergert (1971): Classification and distribution, pp 43-94. In: Lignins: Occurrence, formation, structure and reaction, edited by SARKANEN, K. V. and C. H. Ludwig, Wiley-Interscience, New York.

Seppänen, S.-K., H.-L. Pasonen, S. Vauramo, J. Vahala, M. Toikka, I. KilpeläInen, H. SetÄLÄ, T. H. TeERI, S. Timonen and A. PAPPInEN (2007): Decomposition of the leaf litter and mycorrhiza forming ability of silver birch with a genetically modified lignin biosynthesis pathway. Appl Soil Ecol 36: 100-106.

SMITH, S.E. and D. J. READ (1997): Mycorrhizal symbiosis. $2^{\text {nd }}$ ed, Academic Press, San Diego.

Timonen, H., T. Aronen, T. LaAkso, P. SaranpäÄ, V. ChiANG, T. Ylioja, H. Roininen and H. HäGgMan (2005): Does lignin modification affect feeding preference or growth performance of insect herbivores in transgenic silver birch (Betula pendula Roth)? Planta 222 699-708.

\title{
Genetic Diversity of the Relict Plant Taiwania cryptomerioides Hayata (Cupressaceae) in Mainland China
}

\author{
By Zhong-Chao Li ${ }^{1)}$, XIAo-LAN $\mathrm{WANG}^{2)}$ and Xue-Jun GE ${ }^{1), *)}$
}

(Received 26 ${ }^{\text {th }}$ April 2006)

\begin{abstract}
The genetic diversity and differentiation of five populations of Taiwania cryptomerioides Hayata in mainland China were investigated using inter-simple sequence

1) South China Botanical Garden, The Chinese Academy of Sciences, Guangzhou 510650, P. R. China.

2) Center for Functional Genomics and Microarray, Guangzhou University, Guangzhou 510405

*) Corresponding author: Dr. XuE-Jun Ge. South China Botanical Garden, The Chinese Academy of Sciences, Guangzhou 510650 P. R. China. Tel: +86-20-3725 2551; Fax: +86-20-3725-2831. Email address: gexuejun@mail.sysu.edu.cn, xjge@scbg.ac.cn
\end{abstract}

repeats (ISSR). In comparison with other coniferous species, T. cryptomerioides from mainland China possesses little genetic variation, particularly at the level of individual populations (the percentage of polymorphic loci, Nei's gene diversity and Shannon's indices of diversity at the species and population levels are $38.02 \%$, $0.1326,0.1986$ and $9.27 \%, 0.035,0.0518$ respectively). In contrast, the level of population differentiation is much higher $\left(\mathrm{G}_{\mathrm{ST}}: 0.7269\right.$; Shannon's genetic differentiation: 0.7392; Hickory $\theta^{B}: 0.668$; AMOVA genetic differentiation: $72.37 \%$ ). The genetic divergence of pairs of populations was not significantly correlated with the geographical distance separating them. Current patterns of 
genetic variation were related to biogeographic history and the small population size. On the basis of these findings, we discuss the development of conservation strategies for this endangered species.

Key words: Taiwania cryptomerioides; genetic diversity, ISSR, China, relict species, conservation

\section{Introduction}

Like most of the genera within the Cupressaceae that evolved since the Jurassic period, Taiwania, one of the so-called "living fossils", is considered to be an ancient genus in evolutionary terms with its origin dating back to the Tertiary. According to the fossil evidence, e.g. Taiwania schaeferi Schloem.-Jäg. discovered in Kleinsaubernitz (Germany) (WALTHER, 1999), Spitsbergen (Norway) and Alaska (LePage BA, unpublished data), this genus was widespread in what are now the temperate regions of the northern hemisphere (FLORIN, 1963). Today, Taiwania, a monotypic genus containing only Taiwania cryptomerioides Hayata, has a scattered distribution. Its distributional range covers mountain areas on the border between Burma and China (southwestern part of Yunnan province), the Hoang Lien Son mountain range in northern Vietnam, and Taiwan (FARJON, 2002; FARJON and GARCIA, 2003). Taiwan is an important refuge for T. cryptomerioides: it grows on the Central Mountain at the altitudes of 1600-2600 m, where the largest population and greatest timber yield in the world are found (HUANG, 1983). In addition, there are still a few individuals of T. cryptomerioides in mainland China: in the remote Lichuan mountains in Hubei Province, Leishan mountains in Guizhou Province, and Gutian-Pingnan mountains in Fujian Province. These areas are regarded as having acted as key refugia for relict species during Pleistocene glaciations (WU, 1980; WANG and LIU, 1994). The populations in mainland China have only been widely known to botanists since the early decades of the $20^{\text {th }}$ century, and have sometimes been regarded as comprising a different species, namely T. flousiana Gaussen. Due to human overexploitation in the past century, the conservation status of this species is "vulnerable" according to the IUCN Red List criteria (FARJON, 2001) and it is a protected species in China (FU, 1995).

T. cryptomerioides is a component of evergreen broadleaf forests in mountainous areas. It occurs at an altitude of 500-2800 $\mathrm{m}$ in "coniferous, broad-leaved, or mixed evergreen valley forests on acid, red, or brown soils in warm or warm temperate regions with high summer and autumn rainfall but drier winters, usually scattered and associated with Chamaecyparis formosensis, C. obtusa var. formosana, Cunninghamia lanceolata, Pinus wallichiana, or Tsuga dumosa, but sometimes forming pure stands" (Fu et al., 1999). It can grow as tall as 70 meters and is therefore known as the 'King of Asian Conifers'. This diploid species $(2 \mathrm{n}=22$, LI et al., 2000 ) is wind-pollinated and monoecious, with male and female cones occurring on different branches (FU et al., 1999). With two subapical, unequal wings, seeds of T. cryptomerioides are light and small, and can be carried by wind over long distances.
Information about the genetic structure of a rare species such as this, as well as data on its overall level of genetic diversity, are particularly important for species conservation. Genetic analyses can provide valuable insights into the processes influencing extinction (Clarke and Young, 2000) and, increasingly, genetic data have been used to define conservation management units and to predict changes in population structure and dynamics (NEWTON et al., 1999). However, in comparison with the rarities from Europe and North America, few detailed studies of genetic variation have been undertaken on rare plants in China. Subtropical mainland Asia was one of the most important refugia for plants during the Pleistocene glaciations because it was not covered by ice sheets. Many species that became extinct elsewhere survived in this region, but in a state of isolation and in small populations. Strong genetic differentiation has been discovered in some relict conifer species in China, for example Cathaya argyrophylla ( $\mathrm{GE}$ et al., 1998), Glyptostrobus pensilis (LI and XIA, 2005), Metasequoia glyptostroboides (LI et al., 2005) and Ametotaxus argotaenia (GE et al., 2005). The genetic diversity of T. cryptomerioides from Taiwan has been assessed previously by allozyme (LIN et al., 1993), ISSR and ITS sequence analysis (CHANG, 2005). A low genetic differentiation $\left(\mathrm{G}_{\mathrm{ST}}: 5.2 \%\right.$ based on allozyme data, LIN et al., 1993; $\Phi_{\mathrm{ST}}: 15.26 \%$ using ISSR, CHANG, 2005) was found in the Taiwanese populations. Nevertheless, the intraspecific genetic variation across the distributional range still remains unknown.

Among various molecular tools, the inter-simple sequence repeats (ISSR) method has been widely used for studies of population genetics, because the repeats are highly variable, and the method is economical in terms of time, money, and labor (GUPTA et al., 1994; ZietKiewicz et al., 1994; Tsumura et al., 1996; WolfE and Liston, 1998). ISSRs have also been used to determine the genetic diversity of species of conservation concern (ESSELMAN et al., 1999). Technically, the ISSR reaction is more specific than RAPD amplification due to the longer SSR-based primers (WoLFE and LisTON, 1998). One limitation of the ISSR technique is that the bands are scored as dominant markers and that genetic diversity estimates are based on diallelic characters, thus the level of genetic diversity may be underestimated. The primary objective of this study was to use ISSR markers to investigate genetic variation within and between the extant $T$. cryptomerioides populations in mainland China. We wished to determine whether these populations are strongly differentiated, as is the case for the other relict conifer species mentioned above. The result of this investigation could assist in the development of conservation strategies, by identifying those populations of particular importance in terms of their genetic characteristics.

\section{Material and Methods}

\section{Sample collection}

A total of 104 individuals of Taiwania cryptomerioides was studied, representing four extant wild populations in mainland China and one plantation population (TC) 
Table 1. - Genetic variability within populations of Taiwania cryptomerioides revealed by ISSR (N: sample size per population; $\mathrm{P}$ : percentage of polymorphic loci; $\mathrm{H}_{\mathrm{E}}$ : Nei's gene diversity; Hpop: Shannon indices).

\begin{tabular}{|c|c|c|c|c|c|c|c|c|c|}
\hline $\begin{array}{l}\text { Pop. } \\
\text { code }\end{array}$ & Location & $\begin{array}{l}\text { Coordinates } \\
(\mathrm{N} / \mathrm{E})\end{array}$ & $\begin{array}{l}\text { Elevation } \\
(\mathrm{m})\end{array}$ & Sile type & $\begin{array}{l}\text { Habital } \\
\text { Reference }\end{array}$ & $\mathrm{N}$ & $\begin{array}{l}P \\
(\%)\end{array}$ & $\mathrm{H}_{\mathrm{I}}$ & Hpop \\
\hline $\mathrm{TC}$ & $\begin{array}{l}\text { Tengehong. } \\
\text { Yunnan }\end{array}$ & $25^{\circ} 01^{1} / 98^{\circ} 30^{4}$ & 1700 & Hill, artificial forest & $\begin{array}{l}\text { Feng ot al., } \\
1998\end{array}$ & 11 & 1.56 & 0.0052 & 0.0079 \\
\hline GS & $\begin{array}{l}\text { Gongshan, } \\
\text { Yunnan }\end{array}$ & $27^{\circ} 43^{\prime} / 98^{\circ} 34^{\circ}$ & 2000 & $\begin{array}{l}\text { Valley, scattered } \\
\text { amongst subtropical } \\
\text { evergreen } \\
\text { broadleaved forest }\end{array}$ & $\begin{array}{l}\text { Liu et al., } \\
1987\end{array}$ & 24 & 8.33 & 0.0316 & 0.0469 \\
\hline LS & $\begin{array}{l}\text { Leishan, } \\
\text { Guizhou }\end{array}$ & $26^{\circ} 34^{\prime} / 108^{\circ} 15^{\prime}$ & 1040 & $\begin{array}{l}\text { Valley, scattered } \\
\text { amongst subtropical } \\
\text { evergreen } \\
\text { broadleaved forest }\end{array}$ & $\begin{array}{l}\text { Qiu et al.. } \\
1984\end{array}$ & 21 & 3.65 & 0.0121 & 0.0186 \\
\hline LC & $\begin{array}{l}\text { Lichuan, } \\
\text { Hubei }\end{array}$ & $30^{\circ} 04^{\circ} / 109^{\circ} 05^{\prime}$ & 850 & $\begin{array}{l}\text { Valley, scattered } \\
\text { amongst evergreen } \\
\text { broadleaved forest }\end{array}$ & $\mathrm{Ge}, 1995$ & 22 & 12.50 & 0.0455 & 0.0676 \\
\hline $\mathrm{GP}$ & $\begin{array}{l}\text { Gutian and } \\
\text { Pingnan, } \\
\text { Fujian }\end{array}$ & $\begin{array}{l}26^{\circ} 35-56 \% \\
118^{\circ} 48^{\prime}-119^{\circ} \\
11^{\prime}\end{array}$ & $400-880$ & $\begin{array}{l}\text { Scattered between } \\
\text { village and valley }\end{array}$ & $\begin{array}{l}\text { Yang and } \\
\text { Jiang, } 1999\end{array}$ & 26 & 20.31 & 0.0806 & 0.1179 \\
\hline $\begin{array}{l}\text { Mean } \\
\text { At } \\
\text { species } \\
\text { level }\end{array}$ & & & & & & $\begin{array}{l}21 \\
104\end{array}$ & $\begin{array}{l}9.27 \\
38.02\end{array}$ & $\begin{array}{l}0.035 \\
0.1326\end{array}$ & $\begin{array}{l}0.0518 \\
0.1986\end{array}$ \\
\hline
\end{tabular}

(Table 1, Fig. 1). Among the four wild populations, many individuals are several hundred years old with a DBH greater than $80 \mathrm{~cm}$; their ecological and phytocoenological features have been described previously (Table 1; QIU et al., 1984; LIU et al., 1987; GE, 1995; FENG et al., 1998; YANG and JIANG, 1999). Individuals were sampled at random, regardless of their size and age. Young, healthy leaves were collected in the field, and dried in silica gel prior to DNA extraction. Total DNA was extracted using the CTAB method described by DoYLE (1991) then dissolved in $100 \mu \mathrm{L}$ of TE buffer. DNA concentration was determined by comparison to uncut lambda DNA on $1 \%$ agarose gels; the average DNA concentration was about $20-30 \mathrm{ng} / \mathrm{\mu l}$.

\section{PCR amplification}

PCR amplification was carried out in a volume of $20 \mathrm{\mu l}$; the reaction comprised $20 \mathrm{ng}$ of template DNA, $10 \mathrm{mM}$ Tris- $\mathrm{HCl}(\mathrm{pH} 8.0), 50 \mathrm{mM} \mathrm{KCl,} \mathrm{0.1 \%} \mathrm{Triton} \times 100$, $2.5 \mathrm{mM} \mathrm{MgCl}_{2}, 0.1 \mathrm{mM}$ dNTPs, $2 \%$ formamide, $0.2 \mu \mathrm{M}$ primer and 1.5 units of Taq polymerase. Amplifications were carried out in a PTC-200 thermal cycler (MJ research) following the method of GE and SuN (1999). One hundred primers, each 15-23 nucleotides long (UBC primer set \# 9, Biotechnology Laboratory, University of British Columbia), were screened for the production of a high proportion of polymorphic and reproducible banding. Fifteen primers (UBC \# 807, 808, 811, $826,827,828,835,836,840,846,849,855,866,880$, and 886) fulfilled these requirements. PCR products were electrophoresed on $2.0 \%$ agarose gels buffered with $0.5 \mathrm{x}$ TBE. A 100 bp DNA Ladder (New England Biolabs) was used as a size marker. After staining with ethidium bromide, the fragments were identified using image analysis software for gel documentation (LabWorks Software Version 3.0; UVP, Upland, CA 91786, USA).

\section{Data analysis}

Only bands that could be unambiguously interpreted across all the population samples were used in this study. ISSR profiles were scored as discrete characters (presence or absence of amplified products) for each

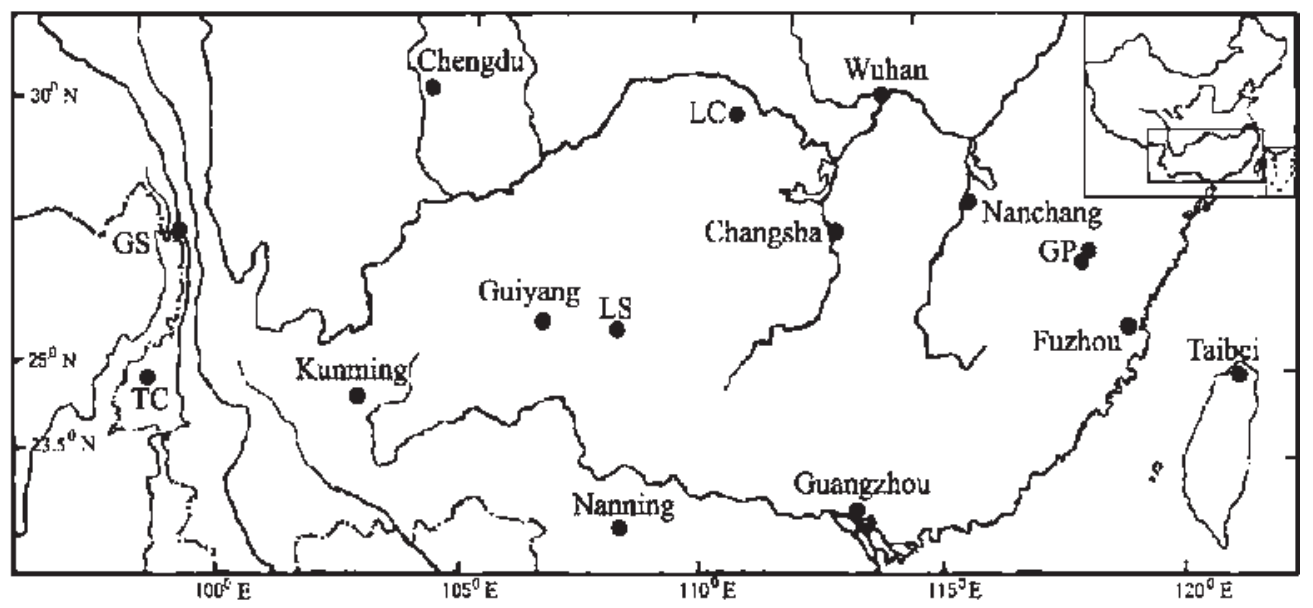

Figure 1. - The sampling locations of Taiwania cryptomerioides Hayata. 
individual. The resulting data matrix was analyzed using POPGENE v. 1.31 (YEH et al., 1999) to estimate genetic diversity parameters: the percentage of polymorphic loci $(P)$ and expected heterozygosity $\left(\mathrm{H}_{\mathrm{E}}\right)$. At the species level, genetic diversity measures $\left(\mathrm{H}_{\mathrm{T}}\right.$ : total gene diversity; $\mathrm{G}_{\mathrm{ST}}$ : coefficient of gene differentiation) and the level of gene flow $(\mathrm{Nm})$ were measured using Nei's (1973) gene diversity statistics. Genetic diversity was also estimated using Shannon's information statistic (Lewontin, 1972): $\mathrm{H}_{\mathrm{Sh}}=-\Sigma p i \log _{2} p_{i}$ where $p_{i}$ is the frequency of a given ISSR fragment. $\mathrm{H}_{\mathrm{Sh}}$ was calculated at two levels: the average diversity within the populations (Hpop), and the total diversity $(H s p)$. Then the proportion of diversity between the populations was estimated as: $(\mathrm{H} s p-\mathrm{H} p o p) / \mathrm{H} s p$.

In addition, an analysis of molecular variance (AMOVA; EXCOFFIER et al., 1992) was used to estimate variance components for ISSR phenotypes, partitioning the variation between populations and between individuals. AMOVA analysis was performed using the Arlequin 2.000 program (SCHNEIDER et al., 2000). To test the presence of isolation by distance, a Mantel test between the pairwise genetic distance and geographic distance from each population pair was applied using Mantel's test in the software TFPGA (MILLER, 1997) (1000 permutations). Pairwise genetic distances $\left(\Phi_{\mathrm{ST}}\right)$ were got from AMOVA analysis, which are analogous to traditional $F$ statistics.

An alternative Bayesian method, allowing direct estimates of $F_{S T}$ from dominant markers without any previous knowledge of $F_{I S}$, was employed to estimate $\theta^{B}$ (analogous to $F_{S T}$ ) using Hickory 1.0 (Holsinger and LEWIS, 2003). Using the default sampling parameters (burn-in $=5000$, sample $=25000$, thin $=5$ ), $\theta^{B}$ was calculated under four different models. The first was a full model, in which both $\theta^{B}$ and $\mathrm{f}$ (i.e., $F_{I S}$, the inbreeding coefficient) were estimated. Two alternative models assumed either $\theta^{B}$ or $f$ equal to zero. Finally, because estimates of $f$ based on dominant markers are usually strongly biased (especially at low sample sizes, i.e., $\mathrm{n}<10$ ), HICKORY was used to construct a model in which $f$ was allowed to vary. The deviance information criterion (DIC) was employed to determine which model was the best fit for the data: lower values indicate a better fit.

\section{Results}

In this study, 73 of the 192 electrophoretic bands $(38.02 \%)$ were polymorphic within the populations. The percentages of polymorphic loci $(P)$ for a single population ranged from $1.56 \%$ (TC) to $20.31 \%$ (GP), with an average of $9.27 \%$. The average genetic diversity was estimated to be 0.0350 at the population level $\left(\mathrm{H}_{\mathrm{S}}\right)$ and 0.1282 at the species level $\left(\mathrm{H}_{\mathrm{T}}\right)$. The Shannon indices were 0.0518 at the population level (Hpop) and 0.1986 at the species level (Hsp), respectively (Table 1). The cultivated TC population exhibited the lowest genetic diversity. Among the four wild populations, population GP had the greatest level of variability $\left(P: 20.31 \%, \mathrm{H}_{\mathrm{E}}\right.$ : 0.0806, Hpop: 0.1179); population LS had the lowest level of variability $\left(P: 3.65 \%, \mathrm{H}_{\mathrm{E}}: 0.0121, \mathrm{H} p o p: 0.0186\right)$ (Table 1). The average polymorphism of the four wild populations was $11.19 \%$.

The coefficient of genetic differentiation between populations $\left(\mathrm{G}_{\mathrm{ST}}\right)$ was 0.7269 , estimated by partitioning the total gene diversity. The Shannon's diversity index analysis partitioned $73.92 \%$ of the total variation between populations, in broad agreement with the result of genetic differentiation analysis. The level of gene flow $(\mathrm{Nm})$ was estimated to be 0.0939 . The AMOVA analysis provided corroborating evidence for the genetic structure obtained from Nei's genetic diversity statistics and Shannon's diversity estimate. There were highly significant $(P<0.001)$ genetic differences between the five populations of $T$. cryptomerioides. Of the total molecular variance, $72.37 \%$ was attributable to between-population diversity and the rest $(27.63 \%)$ to differences between individuals within populations (Table 2). A similar result was obtained from the Hickory calculation: $\theta^{B}$ was 0.668 for the $f$ free model, which had the smallest DIC value.

Genetic distances $\left(\Phi_{\mathrm{ST}}\right)$ between populations of T. cryptomerioides were calculated by Arlequin 2.000 (SCHNEIDER et al., 2000) (Table 3). The highest distance value was 0.9011 between TC and LS, and the lowest was 0.5037 between LS and GP. Geographically TC and GS are the closest pair of sites $(269 \mathrm{~km})$, however, the genetic distance between them, 0.7608, was not the lowest of all the pairs. The result of a Mantel test with 1000 permutations revealed that the genetic divergence of populations was not significantly correlated with geographical distance (Mantel test, $r=-0.3124, P=0.2170$ ).

\section{Discussion}

Low level of genetic diversity and strong genetic differentiation

Correlations between genetic diversity and various attributes of different species have been examined based

Table 3. - The pairwise genetic distance $\left(\Phi_{\mathrm{ST}}\right)$ (below diagonal) and geographic distance ( $\mathrm{km}$ ) (above diagonal).

\begin{tabular}{llllll}
\hline & GP & LS & LC & GS & TC \\
\hline GP & 0.0000 & 1081 & 1052 & 2050 & 2080 \\
LS & 0.5037 & 0.0000 & 421 & 981 & 990 \\
LC & 0.6159 & 0.7871 & 0.0000 & 1085 & 1199 \\
GS & 0.6968 & 0.8604 & 0.7031 & 0.0000 & 269 \\
\hline TC & 0.6471 & 0.9011 & 0.7832 & 0.7608 & 0.9000 \\
\hline
\end{tabular}

Table 2. - Analysis of molecular variance (AMOVA) for five populations of Taiwania cryptomerioides d.f.: degrees of freedom; SS: sum of squares; MS: expected mean squares.

\begin{tabular}{lllllll} 
Source of variation & d.f. & SS & MS & Variance components & \% Total & $P_{\text {-value }}$ \\
\hline Betwoen populations & 4 & 835.7448 & 208.936 & 10.0172 & 72.37 & 60.001 \\
Within population & 99 & 378.5533 & 3.842 & 3.8234 & 27.63 & 0.001
\end{tabular}

a Significance tests after 1000 permutations. 
on a vast amount of data relating to natural plant populations (HAMRICK and GODT, 1989; NYBOM, 2004). Most conifers have high levels of genetic diversity and low levels of differentiation between populations (HAMRICK et al., 1992). Examples include Fitzroya cupressoides (Hpop: 0.547, $\Phi_{\mathrm{ST}}$ : 0.1438; AlLnUTT et al., 1999), Juniperus rigida, J. coreana $\left(\mathrm{H}_{\mathrm{T}}: 0.224\right.$ and $0.199 ; \mathrm{G}_{\mathrm{ST}}: 0.173$ and 0.118, respectively; HuH and HuH, 2000), Cedrus atlantica (Nei's gene diversity within population, $\mathrm{H}_{\mathrm{S}}$ : $0.194 ; \mathrm{F}_{\mathrm{ST}}: 0.148 ; \theta^{B}: 0.178$; RENAU-MorATA et al., 2005) and Juniperus phoenicea $\left(\mathrm{H}_{\mathrm{T}}: 0.148, \mathrm{H}_{\mathrm{S}}: 0.130, \mathrm{G}_{\mathrm{ST}}\right.$ : 0.12; MELONI et al., 2006). Similar genetic diversity and genetic differentiation have also been reported for the Taiwanese populations of T. cryptomerioides (LIN et al., 1993; ChANG, 2005). In this study, however, ISSR polymorphisms revealed a low level of genetic diversity in the mainland populations of $T$. cryptomerioides, with an average of only $11.19 \%$ of ISSR bands being polymorphic in the four wild populations studied. In addition, strong population differentiation was demonstrated based on Nei's gene diversity, Shannon's information statistic, AMOVA and Bayesian estimates. About $70 \%$ of the total genetic variation was partitioned between the populations of $T$. cryptomerioides studied in mainland China.

The low genetic diversity within populations and high genetic differentiation among populations we observed in T. cryptomerioides are similar to that of many relictual endangered conifer species in mainland China. These include Cathaya argyrophylla (GE et al., 1998), Ametotaxus argotaenia (GE et al., 2005), Glyptostrobus pensilis (LI and XIA, 2005), Metasequoia glyptostroboides (Li et al., 2005), Cupressus chengiana (HAO et al., 2006), Torreya jackki (LI and JIN, 2007) and Abies ziyuanensis (TANG et al., 2007) (Table 4). Since these species are characterized by their relict status, biogeographic history may play an important role in determining their genetic diversity. T. cryptomerioides is one of the representatives of relict gymnosperms from the Tertiary period that are found in China. Fossil evidence indicates that the ancestor of T. cryptomerioides was much more widespread during the Tertiary than its current distribution suggests (WALTHER, 1999). Accordingly, a reasonable hypothesis is that the modern range of T. cryptomerioides was the result of population fragmentation and contraction after the Quaternary glacial cycles. The remnant populations contained only part of the genetic variation present before the range reduction. Genetic drift and inbreeding may have further decreased the genetic diversity and increased genetic differentiation in the small, isolated populations of T. cryptomerioides in mainland China.

In addition to historical influences, the present small population size of T. cryptomerioides may be important. According to the literature there are currently about 6000-7000 T. cryptomerioides individuals in mainland China (HU et al., 1995); populations LC and GP are composed of only a dozen individuals (GE, 1995; YANG et al., 2006). This suggests that this species is experiencing erosion of its genetic diversity. In this study, only fourteen electrophoretic bands $(8 \%)$ with a frequency lower

Table 4. - Our results compared with those of relict gymnosperm species endemic to China.

\begin{tabular}{|c|c|c|c|c|c|c|c|c|}
\hline Species & Sampling areas & Populations and individuals & $\begin{array}{l}P(t y) \\
\text { populationi } \\
\text { species }\end{array}$ & $\mid \mathrm{I}_{\mathrm{F}}$ & $\mathrm{H}_{p o p}$ & G Gr & $\begin{array}{l}\text { Molecular } \\
\text { marker }\end{array}$ & Reference \\
\hline Ginkgo biloba & $\begin{array}{l}\text { Thejiang, Guishou, } \\
\text { Ilubei, Jiangsy, New } \\
\text { York }\end{array}$ & $\begin{array}{l}3 \text { malural and } 2 \text { culivaled populations } \\
\text { (66 individuals) }\end{array}$ & $70.45 / 42.95$ & 0.1622 & 0.2385 & 0.3248 & ISSR & $\begin{array}{l}\text { Ge el al., } \\
200,3\end{array}$ \\
\hline $\begin{array}{l}\text { Abiles } \\
\text { sivarafremsis }\end{array}$ & Guangri. I lunan & $\begin{array}{l}7 \text { nantural populacions }(139 \\
\text { individuals }\end{array}$ & $35.73 / 83,60$ & 0.136 & 0.200 & 0.482 & At'I.I & $\begin{array}{l}\text { [ang } \\
\text { al. } 2007\end{array}$ \\
\hline $\begin{array}{l}\text { Amepotans } \\
\text { argoldeptia }\end{array}$ & $\begin{array}{l}\text { Iujjaut, Thejiang, } \\
\text { Guangdong, Jiangxi, } \\
\text { I lubei, J Iunan, Sichuan }\end{array}$ & $\begin{array}{l}10 \text { natural populations (201 } \\
\text { individuals) }\end{array}$ & $9.22 / 64.77$ & 0.0379 & 0.0549 & 0.726 & ISSR & $\begin{array}{l}\text { Ge el al., } \\
2005\end{array}$ \\
\hline $\begin{array}{l}\text { Corbone } \\
\text { argurophyla }\end{array}$ & $\begin{array}{l}\text { Ilunan, } \\
\text { Guangri, Guichual, }\end{array}$ & 8 natural populations ( 101 indiqiduals) & $30.4 / 48.0$ & 0.159 & & 0.441 & Allogme & $\begin{array}{l}\text { Gie el } \mathbf{a} 1 . \\
1998\end{array}$ \\
\hline $\begin{array}{l}\text { Clupesists } \\
\text { cherrgiano }\end{array}$ & Sichuan, Gatısu & 8 natural populations ( 92 individuals) & $47.83 / 98.55$ & 0.3120 & 0.4740 & 0.4791 & ISSR & $\begin{array}{l}\text { llao et al., } \\
2006\end{array}$ \\
\hline $\begin{array}{l}\text { Glypostrobus } \\
\text { pensilis }\end{array}$ & $\begin{array}{l}\text { Guangdong, Jjangxi, } \\
\text { Ilunari, Fujian. Yumnari }\end{array}$ & $\begin{array}{l}14 \text { natura! populations ( } 170 \\
\text { individuals) }\end{array}$ & $10.2 / 24.7$ & & 0.058 & 0.4416 & ISSR & $\begin{array}{l}\text { I.i and } \\
x \text { ia. } 2005\end{array}$ \\
\hline $\begin{array}{l}\text { Metasegtorat } \\
\text { mplostroboides }\end{array}$ & Ilubei, & 8 natural populations (81 isdividuals) & $46.12 / 87.93$ & 0.1832 & 0.2611 & 0.298 & RAI'l & $\begin{array}{l}\text { l.i el al. } \\
2005\end{array}$ \\
\hline Forrekajakii & Zhejiang, linjian & 6 natural populations ( 120 individuals) & $22.56 / 60.48$ & 0.08 & 0.11 & 0.63 & ISSR & $\begin{array}{l}\text { I.i el Jin, } \\
2007\end{array}$ \\
\hline \multirow[t]{3}{*}{$\begin{array}{l}\text { Tarbamia } \\
\text { crpomeriondes }\end{array}$} & laikan & $\begin{array}{l}4 \text { lajwan populations ( } 327 \\
\text { individuals) }\end{array}$ & $50,2 / 53,33$ & & & 0,052 & Allorme & $\begin{array}{l}\text { I.in el al.. } \\
1993\end{array}$ \\
\hline & Taiman, Yurnan & $\begin{array}{l}\text { 8 Iaiwan populations and one Yunnan } \\
\text { population ( } 120 \text { individuals) }\end{array}$ & --170.83 & & & 0.3854 & ISSR & $\begin{array}{l}\text { Chaing, } \\
2005\end{array}$ \\
\hline & $\begin{array}{l}\text { Yunnau, Guizhou. } \\
\text { llubei, I ujjan }\end{array}$ & $\begin{array}{l}3 \text { populations from mainland china } \\
\text { (104 individuals) }\end{array}$ & $9,27 / 38,02$ & 0.1326 & 0.1986 & 0.7237 & ISSR & [his study \\
\hline
\end{tabular}

$P$ : percentage of polymorphic loci; $\mathrm{H}_{\mathrm{E}}$ : Nei's gene diversity; Hpop: Shannon indices; $\mathrm{G}_{\mathrm{ST}}$ : the coefficient of gene differentiation. 
than $30 \%$ were observed, suggesting a possible stochastic process of genetic drift, which could result in the loss of low-frequency alleles in the populations (BROYLES, 1998).

The genetic structure of plant populations reflects the interactions of various evolutionary processes. Low levels of genetic differentiation in gymnosperms are usually attributed to wind-pollination and breeding systems that promote outcrossing. T. cryptomerioides is dioecious, wind pollinated and has light seeds that are usually dispersed by wind (about 1000 seeds in $1.01 \mathrm{~g}$; Chung and ChAng, 1990). It seems likely, therefore, that considerable gene flow should take place between populations. For Taiwan populations of T. cryptomerioides, little genetic differentiation is apparent, thus supporting this suggestion (LIN et al., 1993). In contrast to the geographic proximity of the populations in Taiwan, the populations in mainland China are separated from each other by several hundred kilometers (Table 3). This extreme isolation makes gene flow negligible, resulting in the lack of a correlation between genetic distance and geographical distance found in this study. For example, the genetic distance between populations that are relatively close geographically (i.e., populations TC and GS) was no lower than between geographically more distant ones. The present locations of T. cryptomerioides in mainland China coincide with the key refugia for other relict species during the Pleistocene glaciations (WU, 1980; WANG and LIU, 1994). For example, at the northern limit of this species, Lichuan (LC) in Hubei Province, there are many relict species, including Davidia involucrata, Ginkgo biloba, Keteleeria fortunei, Taxus chinensis, Tetracentron sinensis, Emmenopterys henryi and Bretschneidera sinensis. The famous relic plant Metasequoia glyptostroboides was also discovered in this region in the 1940s (see http://www.metasequoia.org/). This distribution pattern indicates that populations of $T$. cryptomerioides in mainland China may have been isolated from each other since the end of the Pleistocene glaciations.

The high genetic distance between the artificially cultivated TC population and the four wild populations demonstrated that the seed source for this population is unlikely to have been any of the wild populations studied. According to the Flora of Yunnan (Kunming Institute of Botany, 1986), there are still some wild populations of T. cryptomerioides deep in the mountains, on the border between China and Burma. The source of the TC population may be one of these unsampled populations or an extinct local wild population, since the local cultivation history of this species is very long and there are many aged trees in the TC population. According to Farjon (personal communication), the only endemic populations in mainland China are those near the border with Burma, such as population GS in this study. However, his opinion is not supported by the results of this study. In addition, the populations located in the remote mountains were inaccessible by road until the last two decades. More work is needed to identify the source of the propagules from which LC, LS and GP were established. For most conifer species, mtDNA is inherited maternally and is suitable for phylogeographical stud- ies, which can be used to determine a species' natural range (BEEBEE and Rowe, 2004). Further study is needed to screen out the mtDNA fragments with intraspecific polymorphic variation in this species.

\section{Conservation Implications}

The maintenance of genetic diversity is crucial to the survival of organisms, because it allows them to evolve and adapt to changing environmental conditions. The high level of genetic differentiation between the studied populations of Taiwania cryptomerioides indicates that a considerable amount of the overall genetic variation of the species in mainland China would be lost if management concentrated only on the remaining large populations. Therefore, several populations throughout the entire range should be considered for conservation. At present three populations in mainland China (GS, LS and LC) are protected in situ. Despite being situated within a protected area, population LC has been severely affected by land reclamation, and should therefore be accorded a high priority for future conservation action. As for ex situ conservation in botanical gardens, further reduction of genetic variability by genetic drift should be avoided, therefore one additional measure could be artificial gene flow between populations, i.e., artificial introductions should include as many populations as possible.

\section{Acknowledgments}

We thank Mr. Guo-Sheng He, Yong-Fu Yu and YongMING YUAN for their help in collecting samples. This work was supported by the National Natural Science Foundation of China (No. 30170070).

\section{References}

Allnutt, T. R., A. C. Newton, A. Lara, A. Premoli, J. J. Armesto, R. Vergara and M. Gardner (1999): Genetic variation in Fitzroya cupressoides (alerce), a threatened South American conifer. Molecular Ecology 8: 975-987.

BeEBeE, T. J. C. and C. Rowe (2004): An introduction to molecular ecology. Oxford University Press, New York.

Broyles, S. B. (1998): Postglacial migration and the loss of allozyme variation in northern populations of Asclepias exaltata (Asclepiadaceae). American Journal of Botany 85: 1091-1097.

Chang, J. L. (2005): The genetic diversity of Taiwania cryptomerioides Hayata. Master degree thesis. Taiwan: National Sun Yat-sen University.

Chung, Y. L. and N. H. ChANG (1990): Technical report for important tree seeds in Taiwan. Taiwan Forestry Research Institute, Taipei.

Clarke, G. M. and A. G. Young (2000): Introduction: genetics, demography and the conservation of fragmented populations, pp. 1-6. In: Genetics, demography and viability of fragmented populations, edited by A. G. Young and G. M. Clarke, Cambridge University Press, Cambridge.

DoYLe, J. (1991): DNA protocols for plants CTAB total DNA isolation, pp. 283-293. In: Molecular techniques in taxonomy, edited by G. M. HEwitT, A. Johnson and J. P. W. YounG, Springer, Berlin. 
Esselman, E. J., L. JiAnQIANG, D. J. CRAWForD, J. L. WinDUS and A. D. Wolfe (1999): Clonal diversity in the rare Calamagrostis porteri ssp. insperata (Poaceae): comparative results for allozymes and random amplified polymorphic DNA (RAPD) and intersimple sequence repeat (ISSR) markers. Molecular Ecology 8: 443-451.

Excoffier, L., P. E. Smouse and J. M. QuATtro (1992): Analysis of molecular variance inferred from metric distances among DNA haplotypes: application to human mitochondria DNA restriction sites. Genetics 131: 479-491.

FARJON, A. (2001): World checklist and bibliography of conifers, $2^{\text {nd }}$ edn. England: The Royal Botanic Gardens Press, 97.

FARJON, A. (2002): The discovery and protection of a Vietnamese population of Taiwania cryptomerioides. Species 38: 24.

FARJON, A. and S. O. GARCIA (2003). Cone and ovule development in Cunninghamia and Taiwania (Cupressaceae sensu lato) and its significance for conifer evolution. American Journal of Botany 90: 8-16.

FENG, Z. Z., S. Z. YANG and D. M. WANG (1998): Rare trees in Yunnan Province. The China Esperanto Press, Beijing.

FlORIN, R. (1963): The distribution of conifer and taxad genera in time space. Acta Horti Bergiana 20: 121-312.

FU, L. G. (1995): China Plant Red Data Book. Science Press, 1, 118-119, Beijing.

FU, L.G., Y. F. YU and A. FARJON (1999): Cupressaceae, pp. 62-65. In: Flora of China, edited by P. H. RAVEN and C. Y. Wu, Science Press, and St. Louis: Missouri Botanical Garden Press, 4, Beijing.

Ge, J. W. (1995): Preliminary study on Taiwania flousiana community in Maoba, Lichuan county, Hubei Province, pp. 203-214. In: Vegetation of western Hubei Province, edited by J. D. BAN, Huazhong University of Technology Press, Wuhan.

Ge, S., D. Y. Hong, H. Q. WANG, Z. Y. LiU and C. M. Zhang (1998): Population genetic structure and conservation of an endangered conifer, Cathaya argyrophylla (Pinaceae). International Journal of Plant Sciences $\mathbf{1 5 9}$ 351-357.

Ge, X. J., X. L. Zhou, Z. C. Li, T. W. Hsu, B. A. SchaAl and T. Y. CHIANG (2005): Low genetic diversity and significant population structuring in the relict Amentotaxus argotaenia complex (Taxaceae) based on ISSR fingerprinting. Journal of Plant Research 118: 415-422.

Ge, Y. Q, Y. X. QIU, B. Y. Ding and C. X. Fu (2003): An ISSR analysis on population genetic diversity of the relict plant Ginkgo biloba. Biodiversity Science 11: 276-287.

Gupta, M., Y. S. Chyi, J. Romero-Severson and J. L. OWEN (1994): Amplification of DNA markers from evolutionarily diverse genomes using single primers of simple sequence repeats. Theoretical and Applied Genetics 89: 998-1006.

Hamrick, J. L., M. J. W. Godt and S. L. Sherman-Broyle (1992): Factors influencing levels of genetic diversity in woody plant species. New Forest 6: 95-124.

HAMrick, J. L. and M. J. W. GoDT (1989): Allozyme diversity in plant species, pp. 43-63. In: Plant population genetics, breeding and genetic resources, edited by A. H. D. Brown, M. T. ClegG, A. L. Kahler and B. S. WEIR, Sinauer Associates, Sunderland.

HaO, B. Q., L. Wang, L. C. Mu, L. YaO, R. Zhang, M. X. TANG and W. K. BAO (2006): A study of conservation genetics in Cupressus chengiana, an endangered endemic of China, using ISSR markers. Biochemical Genetics 44: 29-43.

Holsinger, K. E. and P. O. Lewis (2003): HICKORY: a package for analysis of population genetic data V1.0. Department of Ecology and Evolutionary Biology, University of Connecticut, USA. Available at website http://darwin.eeb.uconn.edu/hickory/hickory.html

Hu, Y. S., J. X. Lin, X. P. WANG and L. B. WeI (1995): The biology and conservation of Taiwania cryptomerioides. Chinese Biodiversity 3: 206-212.

HuAng, W. (1983): The vegetation of Taiwan. China Environment Science Press, Beijing.

HuH, M. K. and H. W. HuH (2000): Genetic diversity and population structure of Juniperus rigida (Cupressaceae) and J. coreana. Evolutionary Ecology 14: 87-98.

KunMING INSTITUTE OF BotanY (1986): Flora of Yunnan, Volume 4. Science Press, Beijing.

Lewontin, R. C. (1972): The apportionment of human diversity. Evolutionary Biology 6: 381-398.

LI, F. G. and N. H. XIA (2005): Population structure and genetic diversity of an endangered species, Glyptostrobus pensilis (Cupressaceae). Botanical Bulletin of Academia Sinica 46: 155-162.

LI, J. and Z. JIN (2007): Genetic variation and differentiation in Torreya jackii Chun, an endangered plant endemic to China. Plant Science 172: 1048-1053.

LI, L. C., S. SU and J. H. JIANG (2000): Karyotype analysis of Chamaecparis obtusa var. formosana (Cupressaceae) and Taiwania cryptomerioides (Taxodiaceae). Journal of Fudan University (Natural Science) 39: 569-571.

Li, Y. Y., X. Y. Chen, X. Zhang, T. Y. WU, H. L. LU and Y. W. CAI (2005): Genetic differences between wild and artificial populations of Metasequoia glyptostroboides $\mathrm{Hu}$ et Cheng (Taxodiaceae): Implications for species recovery. Conservation Biology 19: 224-231.

Lin, T. P., C. S. LU, Y. L. Chung and J. C. YANG (1993): Allozyme variation in four populations of Taiwania cryptomerioides in Taiwan. Silvae Genetica 42: 278-284.

LIU, L. H., J. H. Zhang and Y. D. Yu (1987): Studies on the natural Taiwania flousiana forest and their communities in Yunnan province. Acta Phytoecologica Sinica 11: 220-225.

Meloni, M., D. Perini, R. Filigheddu and G. Binelli (2006): Genetic variation in five mediterranean populations of Juniperus phoenicea as revealed by Inter-Simple Sequence Repeat (ISSR) markers. Annals of Botany 97: 299-304.

MILlER, M. P. (1998): AMOVA-PREP 1.01: A program for the preparation of AMOVA input files from dominantmarkers raw data. Computer software distributed by author.

NeI, M. (1973): Analysis of gene diversity in subdivided populations. Proceedings of the National Academy of Sciences of the United States of America. 70: 3321-3323.

Newton, A. C., T. Allnutt, A. C. M. Gillies, A. Lowe and R. A. EnNos (1999): Molecular phylogeography, intraspecific variation and the conservation of tree species. Trends in Ecology and Evolution 14: 140-145.

Nyвом, H. (2004): Comparison of different nuclear DNA markers for estimating intraspecific genetic diversity in plants. Molecular Ecology 13: 1143-1155.

QIU, X. Q., S. Y. WU and K. H. LONG (1984): Investigation of Taiwania flousiana forests of Leigong mountain preserve in Guizhou Province. Acta Phytoecologica Sinica 8: $264-278$. 
Renau-Morata, B. R., S. G. Nebauer, E. Sales, J. Allainguillaume, P. Caligari and J. Segura (2005): Genetic diversity and structure of natural and managed populations of Cedrus atlantica (Pinaceae) assessed using random amplified polymorphic DNA. American Journal of Botany 92: 875-884.

Schneider, S., D. Roessli and L. Excoffier (2000): Arlequin ver. 2.000: A software for population genetics data analysis, Genetics and Biometry Laboratory, University of Geneva, Switzerland.

TANG, S. Q., W. J. DAI, M. S. LI, Y. Zhang, Y. P. GENG, L. WANG and Y. ZHONG (2007): Genetic diversity of relictural and endangered plant Abies ziyuanensis (Pinaceae) revealed by AFLP and SSR markers. Genetica in press.

Tsumura, Y., K. OHBA and S. H. Strauss (1996): Diversity and inheritance of inter-simple sequence repeat polymorphisms in Douglas-fir (Pseudotsuga menziesii) and sugi (Cryptomeria japonica). Theoretical and Applied Genetics 92:

WALther, H. (1999): Die Tertiaerflora von Kleinsaubernitz bei Bautzen. Palaeontographica Abteilung B 249: 63-174.
WANG, X. P. and Y. K. LIU (1994): Theory and practice of biodiversity. China Environmental Science Press, Beijing.

WolfE, A. D. and A. LiSTON (1998): Contributions of PCRbased methods to plant systematics and evolutionary biology, pp. 43-86. In: Plant molecular systematics II, edited by D. E. Soltis, P. S. Soltis and J. J. Doyle, Kluwer, Boston.

WU, Z. Y. (1980): The vegetation of China. Science Press, Beijing.

YANG, Q. J., H. XU, Z. G. YAN, Y. LIU, K. G. ZhaO and L. Q. CHEN (2006): Natural resources and conservation of Taiwania cryptomerioides in Hubei Province. Guihaia 26: 551-556.

YANG, W. M. and S. Y. JIANG (1999): Investigation of relict Taiwania flousiana in Fujian Province. Forest By-Product and Speciality in China 4: 55-57.

YeH, F. C., R. C. YANG and T. Boyle (1999): POPGENE. Microsoft windows Based Freeware for Population Genetic Analysis Release 1.31, University of Alberta, Edmonton.

ZietKiewicz, E., A. RAFALski and D. LABUdA (1994): Genome fingerprinting by simple sequence repeat (SSR)-anchored polymerase chain reaction amplification. Genomics 20: 176-183.

\title{
Genetic Variation Within Two Sympatric Spotted Gum Eucalypts Exceeds Between Taxa Variation
}

\author{
By J. W. OChIENG ${ }^{1), 4), *)}$, M. ShePherD ${ }^{1)}$, P. R. BAVERStock ${ }^{1)}$, G. NiKLES ${ }^{2)}$, D. J. LeE ${ }^{3)}$ and R. J. HenRY ${ }^{1)}$
}

(Received 29 $9^{\text {th }}$ April 2007)

\begin{abstract}
Population substructure and hybridization, among other factors, have the potential to cause erroneous associations in linkage disequilibrium $(L D)$ mapping. Two closely related spotted gum eucalypts, Corymbia variegata and C. henryi (Myrtaceae) occur in sympatry in the east coast of Australia and potentially interbreed. They are morphologically similar but are distinguished as separate species based on capsule and foliage size. To determine whether they hybridize in nature and its

1) Centre for Plant Conservation Genetics, Southern Cross University, P. O. Box 157 Lismore, NSW, 2480, Australia.

2) Department of Primary Industries and Fisheries, 80 Meiers Road, Indooroopilly, Queensland, Australia.

${ }^{3}$ ) Department of Primary Industries and Fisheries, LB 16 Fraser Road, Gympie 4570, Queensland, Australia.

4) Permanent address: Faculties of Agriculture \& veterinary Medicine, University of Nairobi, P.O. Box 30197 Nairobi, Kenya. E-mail: jochieng@uonbi.ac.ke

*) Communicating author: Joel W. OChieng. Centre for Plant Conservation Genetics, Southern Cross University, P.O. Box 57 Lismore, NSW 2480 Australia. Tel: +61 26620 3961; Fax: +6126622 2080. E-mail: jochieng@uonbi.ac.ke
\end{abstract}

implications for $L D$ mapping, we investigated the level of molecular divergence between the two species at two sympatric locations separated by 300 kilometres. Very few individuals of intermediate morphology were identified, despite the two species occurring only metres apart. Analysis of genetic structure using 12 microsatellite loci showed that genetic differentiation between populations of the same species at different locations $\left(F_{\mathrm{ST}}=0.07\right.$ for both species; $\left.p=0.0001\right)$ was significantly higher than that observed between species at each location (mean $F_{\mathrm{ST}}=0.02$ and 0.04 for Cherry tree and Bunyaville respectively; $p=0.0001$; all Mann-Whitney $U$-test $p \leq 0.01)$. No species-specific alleles or significant allele frequency differences were detected within a site, suggesting recurr\#ent local gene flow between the two species. The lack of significant allele frequency differences implies no population stratification along taxonomic lines. This suggested that there is little concern for cryptic hybridization when sampling from sites of sympatry for $L D$ mapping.

Key words: panmixia, hybridization, gene flow, association mapping, population structure, admixture, reproductive isolation, linkage disequilibrium. 